\title{
Peningkatan Omset Penjualan Melalui Penerapan Teknologi Mesin Pengering Ramah Lingkungan Dan Pemasaran On Line
}

\author{
Kemas Muhammat Abdul Fatah ${ }^{1}$, Nelson ${ }^{1}$, Ruslan Dalimunthe ${ }^{1}$ \\ Universitas Sang Bumi Ruwa Jurai \\ kmsmafattah@gmail.com,nelsonsaburai@gmail.com, ruslandalimunthe652@gmail.com
}

\begin{abstract}
Abstrak
Agroindustri emping Melinjo di Provinsi Lampung berpotensi untuk dikembangkan mengingat pasokan bahan baku Melinjo yang berlimpah dan didukung keberadaan agroindustri emping Melinjo yang tersebar di banyak tempat. Salah satu klaster agroindustri emping Melinjo yang tersebar di Provinsi Lampung berada di Kelurahan Way Tataan kecamatan Teluk Betung Timur, terdapat 50 kepala keluarga produsen emping Melinjo skala rumah tangga (mikro), salah satunya adalah ibu Dewi yang menjadi mitra program ini. Berdasarkan hasil pengamatan dari permasalahan yang dihadapi dan sesuai hasil diskusi, permasalahan prioritas yang akan dicarikan solusi adalah terkait dengan proses penjemuran dan perluasan pasar. Pada proses penjemuran akan diterapkan teknologi mesin pengering ramah lingkungan dimana energi panas matahari sebagai sumber panas, sehingga kapasitas produksi dapat ditingkatan mencapai $40 \%$. Terkait dengan perluasan pasar, mitra akan diberikan pelatihan dan pendampingan terkait dengan pemasalahan online, diharapkan 50\% dari hasil produksi terserap pasar online. Program ini dimulai dari kegiatan survey, untuk mengindentifikasi permasalahan dan kebutuhan Mitra, berikutnya adalah pembuatan dan uji coba mesin dan secara paralel akan dilakukan pelatihan dan pendampingan pemasaran online. Luaran dari penelitian ini, selain $40 \%$ peningkatan kapasitas produksi dan 50\% hasil produksi dijual secara online, luaran yang lain adalah hasil PKM didesiminasikan di Seminar Nasional dan dipublikasikan di prosiding Seminar Nasional.
\end{abstract}

Kata Kunci : Agroindustri, Emping Melinjo, Pasar Online, Teknologi

\begin{abstract}
Melinjo chips agro-industry in Lampung Province has the potential to be developed considering the abundant supply of Melinjo raw materials and supported by the existence of Melinjo chips agro-industry which is spread in many places. One of the Melinjo chips agroindustry clusters spread across Lampung Province is Kelurahan Way Tataan, Kecamatan Teluk Betung Timurt, there are 50 heads of families producing Melinjo chips on a household scale (micro), one of whom is Ibu Dewi who is a partner of this program. Based on the observations of the problems encountered and according to the results of the discussion, the priority problems that will be sought for solutions are related to the drying process and market expansion. In the drying process, environmentally friendly drying machine technology will be applied where solar thermal energy is the heat source, so that production capacity can be increased to $40 \%$. Regarding market expansion, partners will be given training and assistance related to online problems, it is expected that $50 \%$ of the production will be absorbed by the online market. This program starts from survey activities, to identify the problems and needs of Partners, the next is the manufacture and testing of machines and parallel training and online marketing assistance will be carried out. The output of this research, apart from a $40 \%$ increase in production capacity and 50\% of production sold online, the other output is that the PKM results are disseminated at the National Seminar and published in the proceedings of the National Seminar.
\end{abstract}




\section{PENDAHULUAN}

Pulau Sumatera merupakan salah satu penghasil tanaman Melinjo. Melinjo Sumatera ini lebih dikenal dengan Melinjo Lampung karena pintu keluar Melinjo Sumatera berada di Provinsi Lampung. Sebagai sentra produksi Melinjo, total produksi Melinjo Provinsi Lampung pada tahun 2019 sebesar 14.076 kwintal (Badan Pusat Statistik, 2020). Agroindustri emping Melinjo di Provinsi Lampung mempunyai potensi untuk dikembangkan mengingat pasokan bahan baku Melinjo berlimpah dan didukung dengan keberadaan agroindustri emping Melinjo yang tersebar di banyak tempat. Salah satu klaster agroindustri emping Melinjo yang tersebar di Provinsi Lampung berada di Kelurahan Way Tataan kecamatan Teluk Betung Timur. Di Kelurahan Way Tataan kecamatan Teluk Betung Timur ini terdapat 50 kepala keluarga produsen emping Melinjo skala rumah tangga (mikro). Berdasarkan sebaran penduduk menurut mata pencaharian, agroindustri emping Melinjo menempati posisi ke empat yang mendominasi mata pencaharian di Kelurahan Way Tataan kecamatan Teluk Betung Timur. Setiap produsen emping Melinjo bisa mempekerjakan 25 orang tenaga kerja yang berasal dari masyarakat yang tinggal di sekitar agroindustri emping Melinjo tersebut. Oleh karena itu, eksistensi pengusaha emping Melinjo terhadap lingkungan sangat mendukung pemberdayaan khususnya kaum wanita yang umumnya tamat SD untuk dilibatkan dalam pengembangan usaha emping Melinjo ini, serta merupakan salah satu upaya untuk mengurangi penggangguran.

Agrobisnis emping Melinjo di Desa Way Tataan memiliki potensi yang besar untuk dikembangkan sebagai sumber perekonomian masyarakat yang dapat meningkatkan kesejahteraan masysrakat, hal ini terlihat dari berlimpahnya bahan baku emping Melinjo yang berupa buah Melinjo. Dikarenakan buah Melinjo tidak terserap oleh agroindustri emping Melinjo, sebagian petani Melinjo menjual hasil panen dalam bentuk klatak dengan alasan ingin cepat memperoleh uang untuk membiayai kebutuhan hidupnya. Keadaan seperti ini sering dimanfaatkan oleh pedagang tengkulak untuk memperoleh keuntungan, mereka akan memborong biji klatak secara murah pada saat panen raya kemudian menjualnya di luar musim panen, tentunya dengan harga yang berlipat ganda.

Sedemikian penting agroindustri emping Melinjo bagi perekonomian masyarakat, namun tata kelola agroindustri ini belum dilakukan dengan baik sehingga hasil produksi masih kecil sementara pasokan bahan baku berlimpah, omset penjualan masih terlalu kecil dibandingkan dengan bahan baku yang tersedia. Hal ini terlihat dari sisi pemasaran, hasil produksi hanya dijual kepada pengumpul atau menunggu pembeli yang datang tanpa diberi kemasan.

Salah satu produsen emping Melinjo yang ada di Kelurahan Way Tataan adalah ibu Dewi, mitra dalam program PKM ini. Ibu Dewi telah menjalankan usaha agrobisinis ini sudah cukup lama 
dengan dibantu oleh keluarga terdekat dan tetangga, dan usaha ini menjadi sumber penghasilan utama bagi keluarga. Berdasarkan pengamatan yang dilakukan oleh Tim Pengadian Universitas Sang Bumi Ruwa Jurai, ibu Dewi di dalam menjalankan usahanya dilakukan dengan sangat sederhana, tanpa sentuhan manajemen dan teknologi.

Ibu Dewi mendapatkan bahan baku yang sudah berupa klatak, yang dibeli dari pengepul atau biasa mereka sebut dok. Sementara untuk proses produksinya sendiri adalah sangat sederhana seperti yang tampak pada Gambar 1 .

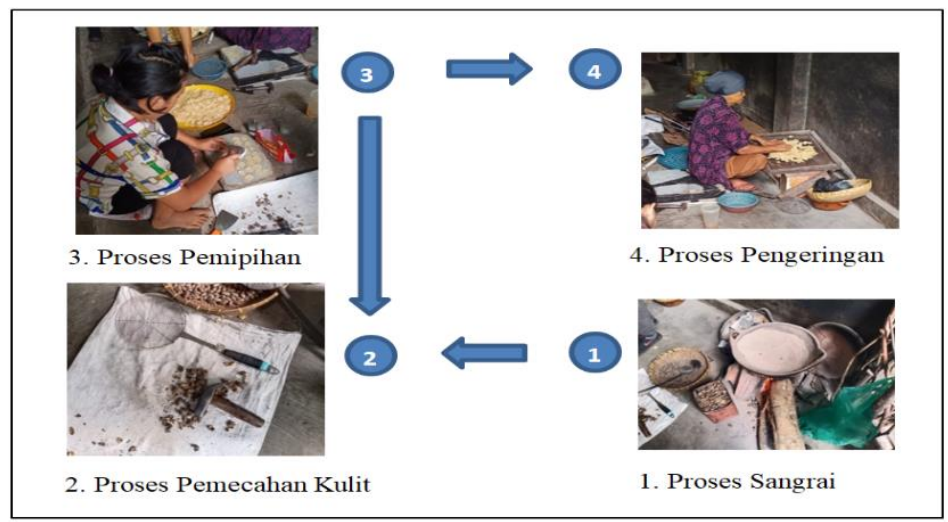

Gambar 1. Aliran Proses Produksi Ibu Dewi

Permasalahan yang terkait dengan agroindustri emping melinjo telah dibahas di dalam beberapa penelitian. Hudaya (Hudaya, 2006) melakukan penelitian dengan hasilnya adalah bahwa usaha emping melinjo dapat meningkatkan pendapatan sampai sebesar 56.2\% dibandingkan usaha biji melinjo. Terkait dengan perbaikan proses produksi, implementasi teknologi dapat dilakukan seperti perancangan alat pengupas kulit luar melinjo (Arkha, 2017) yang mampu meningkatkan proses pengupasan, perancangan alat sangai (Prasetya, 2019) yang mampu meningkatkan proses penyanggraian, pembuatan alat pengepres biji melinjo (Yanto dkk, 2018) yang dapat meningkatkan proses pengepresan.

Berdasarkan penelitian yang telah diuraikan di atas, dapat menjadi referensi untuk mendorong Mitra fokus pada usaha emping melinjo sehingga dapat meningkatkan omset melalui implementasi teknologi dan pemasaran online.

\section{METODE PELAKSANAAN}

Metode yang digunakan dalam pelaksanaan kegiatan PKM ini adalah berdasarkan input, proses dan output, seperti yang tampak pada Gambar 2 di bawah ini. 


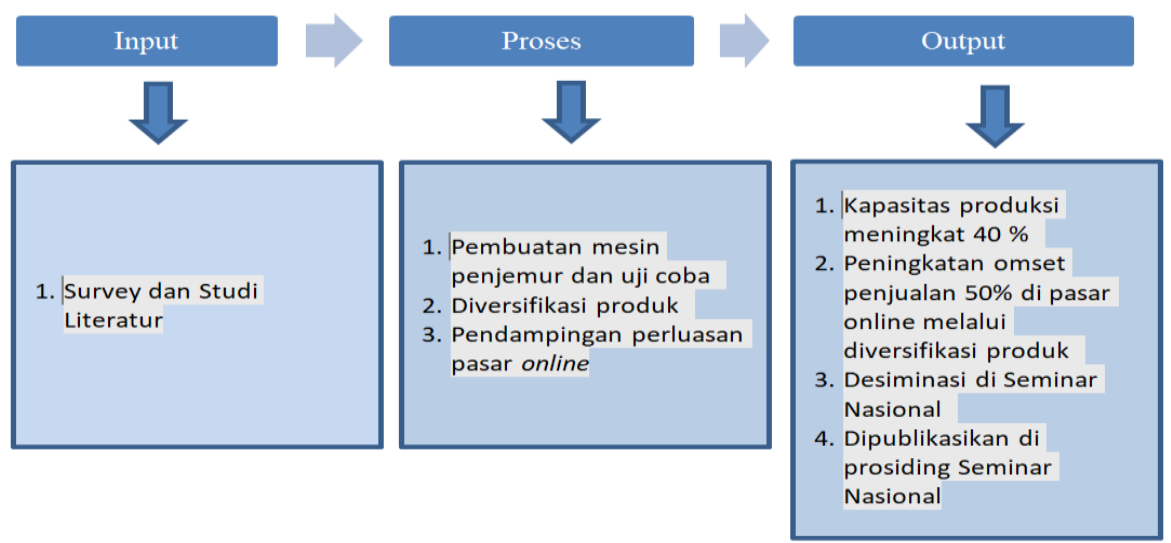

Gambar 2. Skema Metode Pelaksanaan

Berdasarkan Gambar 2, tahapan pelaksanaan PKM dapat diuraikan sebagai berikut:

\section{Survey dan Studi Literatur}

Tim PKM dari Universitas Sang Bumi Ruwa Jurai melakukan observasi dan wawancara dengan petani Melinjo dan pelaku usaha mikro agroindustri emping, serta dengan Sekretaris Kelurahan.

Observasi dan wawancara dilakukan untuk mengetahui bagaimana tata kelola usaha mikro agroindustry dan permasalahan yang dihadapi. Survey untuk mengindentifikasi teknologi tepat guna yang bisa meningkatkan produktifitas dan peluang perluasan pasar. Survey juga untuk membuat kesepakatan program PKM.

\section{Pembuatan mesin penjemur dan uji coba}

Tim PKM merancang mesin dan akan difabrikasi atas persetujuan mitra. Fabrikasi komponen dilakukan di Universitas Sang Bumi Ruwai.

\section{Diversifikasi produk}

Dengan adanya peningkatan kapasitas produksi perlu diimbangi dengan serapan pasar sehingga peningkatan produksi dapat meningkatkan omset penjualan. Mitra akan didorong untuk diversifikasi produk sebagai alternatif penyerapan kapasitas produksi, dimana emping melinjo tidak hanya dijual dalam kemasan emping melinjo siap santap, tetapi juga dalam bentuk kemasan emping mentah.

\section{Pendampingan perluasan pasar}

Untuk meningkatkan omset penjualan tentu harus dilakukan perluasan pasar, produk dalam kemasan emping melinjo mentah dapat dijual secara online dimana dapat dijual melalui 
marketplace. Mitra akan diberi pelatihan bagaimana menjual produk melalui marketplace dan diberikan pendampingan.

\section{HASIL DAN PEMBAHASAN}

\section{Mesin Pengering Ramah Lingkungan}

Mesin pengering ini berdimensi $80 \times 60 \times 80 \mathrm{~cm}$. Bahan-bahan yang digunakan dalam pembuatan mesin pengering ini mempunyai beberapa karakteristik khusus. Pertama, dipilih bahan yang harganya terjangkau dengan harapan dalam aplikasinya menghemat dari sisi harga. Kedua, mesin pengering dapat dipindahkan atau digerakkan sehingga dapat diarahkan ke arah matahari untuk mendapatkan kekuatan panas matahari yang maksimal. Ketiga, Bahan yang dipilih memiliki sifat kolektor panas, yaitu porous absorber sehingga panas akan terakumulasi di dalam alat sehingga dapat mempercepat proses pengeringan. Terakhir, prototipe alat ini juga dibuat dari bahan yang tidak mudah pecah, patah atau keropos sehingga dapat mengurangi resiko kerusakan dan kerugian. Besi hollow ukuran 10 x 20 terbuat logam yang digunakan sebagai rangka merupakan bahan konduktor panas yang baik, ringan dan terjangkau.

Acrylic transparan yang berfungsi sebagai sisi atas digunakan dengan tujuan optimalisasi penyerapan sinar matahari sebagai sumber energi utama. Untuk kolektor panas digunakan bahan dari seng yang dicat dengan warna hitam. Seng hitam ini merupakan konduktor (penghantar) panas yang baik.

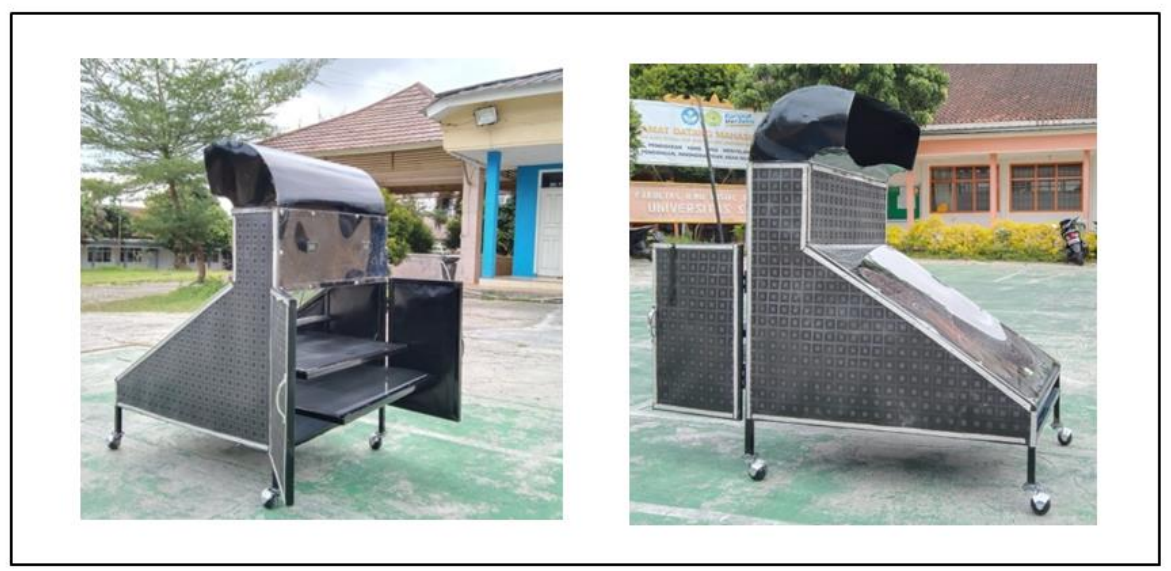

Gambar 3. Mesin Pengering Ramah Lingkungan

\section{Diversifikasi Produk}

Dengan diimplementasikannya mesin pengering ramah lingkungan yang dapat meningkatkan kapasistas produksi, diperlukan diversifikasi produk untuk meningkatkan penjualan, dimana produk tidak dijual hanya dalam kemasan siap santap tetapi juga dalam kemasan emping melinjo mentah. 


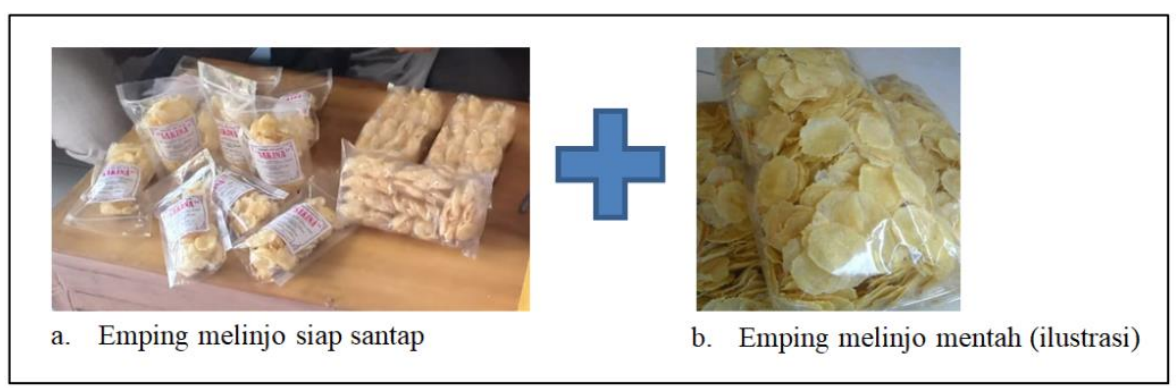

Gambar 4. Hasil Diversifikasi Produk

\section{Perluasan Pasar}

Usaha untuk peningkatan penjualan tidak cukup dengan diversifikasi produk, diperlukan usaha perluasan pasar sehingga hasil produksi yang meningkat dapat terserap yang dapat meningkatkan omset penjualan. Pada PKM ini, diberi pelatihan dan pendampingan penjualan online melalui marketplace untuk perluasan pasar.

\section{Desiminasi dan Publikasi}

Hasil PKM ini telah dipresentasikan secara oral pada Seminar Nasional II pada tanggal 14 Desember 2021, yang diselengarakan oleh Lembaga Penelitian dan Pengabdian kepada Masyarakat (LPPM) Universitas Sang Bumi Ruwa dan akan dimuat dalam prosiding yang dipublikasikan.

\section{KESIMPULAN}

Berdasarkan kegiatan Pengabdian kepada Masyarakat dapat disimpulkan bahwa: 1) Mesin pengering emping melinjo ramah lingkungan yang diperkenalkan dalam program ini mampu memperbaiki proses produksi, dimana dapat meningkatkan kapasitas produksi sebesar 40\%. 2) Kenaikkan kapasitas produksi sebesar 40\%, mendorong Mitra melakukan diversitifikasi produk, dimana pada awalnya memproduksi emping melinjo siap konsumsi, produknya bertambah dengan menjual emping melinjo setengah jadi (emping melinjo mentah. 3) Peningkatan kapasitas produksi juga diiringi dengan peningkatan omset penjualan dimana pemasaran juga melalui marketplace setelah diberi pelatihan.

\section{Saran}

Berdasarkan Pengabdian yang dilakukan, beberapa saran yang diharapkan dapat bermanfaat adalah sebagai berikut : 1) Kapasitas pengeringan dari mesin pengering dalam program PkM kali ini masih relatif kecil sehingga perlu diperbesar. 2) Mesin pengering ini perlu diperkenalkan kepada UKM lain, sehingga UKM lain juga bisa meingkatkan kapasitas produksi. 


\section{UCAPAN TERIMA KASIH}

Penulis mengucapkan terima kasih kepada Yayasan Pendidikan Saburai yang telah mendanai program PKM ini, dan kepada LPPM Universitas Sang Bumi Ruwa Jurai yang telah melaksanakan program hibah mandiri Penelitian dan PKM tahun 2021.

\section{DAFTAR PUSTAKA}

Badan Pusat Statistik, Kota Bandar Lampung Dalam Angka 2020. Badan Pusat Statistik Kota Bandar Lampung, 2020.

A. R. Hudaya, "Analisis usahatani biji melinjo dan emping melinjo (Gnetum gnemon L)," $J$. AGRIJATI, vol. 3, no. 1, pp. 51-59, 2006.

A. Arkha, T. Atmodjo, and E. Noviyanto, "Perancangan Mesin Pengupas Kulit Luar Buah Melinjo Model Roll Gerigi Kapasitas 120 Kg / Jam," vol. 1, 2017.

A. Y. Prasetya, P. Studi, T. Industri, F. Teknik, and U. M. Surakarta, "Perancangan alat sangrai dalam pembuatan emping melinjo menggunakan pendekatan benchmarking," 2019.

M. Sari, S. Yanto, and M. Yahya, "Pembuatan Alat Pengepres Biji Melinjo Sebagai Teknologi Tepat Guna Untuk Mengolah Biji Melinjo Menjadi Emping," J. Pendidik. Teknol. Pertan., vol. 2, p. 22, 2018, doi: 10.26858/jptp.v2i0.5182. 